\title{
Provenience bílého mramoru $z$ archeologické lokality San Severo v Classe (Ravenna, Itálie)
}

\author{
Provenance of white marble from the archaeological site of San Severo in Classe \\ (Ravenna, Italy)
}

Helena Tůmová1 $\square$, Dalibor Všianskýn ${ }^{2}$, Enrico Cirelli³, Aleš Frýbort ${ }^{4}$

${ }^{1}$ Institut pro klasickou archeologii FF UK, Celetná 20, Praha 1, ČR

2 Ústav geologických věd PřF MU, Kotláŕská 267/2, 61137 Brno, ČR

${ }^{3}$ Dipartimento di Storia Culture Civiltà, Università di Bologna, San Vitale 28, Ravenna, Itálie

${ }^{4}$ Centrum dopravního výzkumu, v.v.i., Lišeňská 33a, 63600 Brno, ČR

Key words:

white marble, provenance determination, marble importation, Late Antiquity, Middle Ages, Ravenna, Italy, Proconnesos, Mediterranean

$\square$ helena.tumova@ff.cuni.cz

Editor:

David Buriánek

\begin{abstract}
The article deals with the provenance of white marbles from the late antique and early medieval ecclesiastical complex of San Severo in Classe (Ravenna, Italy), presents the results of an archaeometric study, concerning mineralogical, petrographic and geochemical analyses (X-RAY diffraction, scanning electron microscopy and X-RAY microanalysis, optical polarization microscopy, determination of the $\delta^{13} \mathrm{C}$ and $\delta^{18} \mathrm{O}$ stable isotopic ratios) and compares them with the main databases of Mediterranean white marbles quarried during Late Antiquity. The import of the Proconnesian marble from Marmara Island to the North Adriatic region, Ravenna and Classe not excluded, during Late Antiquity is generally presupposed in the scientific literature. The provenance of five analyzed samples of white-grey marble has been proposed. The results of analyzes indicate their Eastern provenance: four samples have been identified as the Proconnesian marble (Proconnesos 1 or Proconnesos 2). The provenance of one sample does not appear to be entirely certain, in any case, both point to microasiatic provenance: Muğla (Göktepe) or Docimium seem to be the most probable of the considered localities.
\end{abstract}

\section{Doporučená citace článku:} Tůmová, H., Všianský, D., Cirelli, E., Frýbort, A. (2021). Provenience bílého mramoru z archeologické lokality San Severo v Classe (Ravenna, Itálie). - Geologické výzkumy na Moravě a ve Slezsku, 28, 1-2, 50-59.

https://doi.org/10.5817/GVMS202114177

\section{Úvod}

Mramorovým artefaktům ravennského uměleckého okruhu je tradičně připisována východní provenience, zejména je-li řeč o bílém či bílo-šedém mramoru. Východní orientaci pozdně antické Ravenny (obr. 1a) potvrzují rovněž četné umělecké analogie, které lze spatřovat v typologii architektonické dekorace či ravennských sarkofágů, představujících unikátní soubor umění (Sekavová 2006) a dokládajících živé vztahy mezi Ravennou, Konstantinopolí a maloasijskými oblastmi (a to zejména díky importu finálních či prefabrikovaných artefaktů). Kamenný materiál z archeologických výzkumů na lokalitě basiliky San Severo a přilehlého kláštera v Classe (obr. 1b), čítající více než 1000 fragmentů, byl nejprve zkoumán z makroskopického hlediska (barva, struktura, zrnitost, žilkování, způsob opracování, sekundární nečistoty jako jsou zbytky omítky či malty, kovových skob apod.), na základě něhož byly identifikovány jednotlivé litotypy, $\mathrm{z}$ nichž nejčetněji zastoupenou skupinu tvořily metamorfované horniny (mramory) v celkovém zastoupení $65 \%$ (Tůmová 2013). Z nich pak $96 \%$ představoval bílý (resp. bílo-šedý), převážně hrubozrnný mramor a $4 \%$ mramor polychromní: marmor Iassense - „cippolino rosso“ a marmor Carystium - „cippolino verde“ (Tůmová 2013). Z makroskopického pozorování bílo-šedého mramoru z lokality San Severo a mramorových artefaktů z okruhu ravennského umění (mramorové architektonické články ravennských basilik, sarkofágy atd.), u nichž je v odborné 


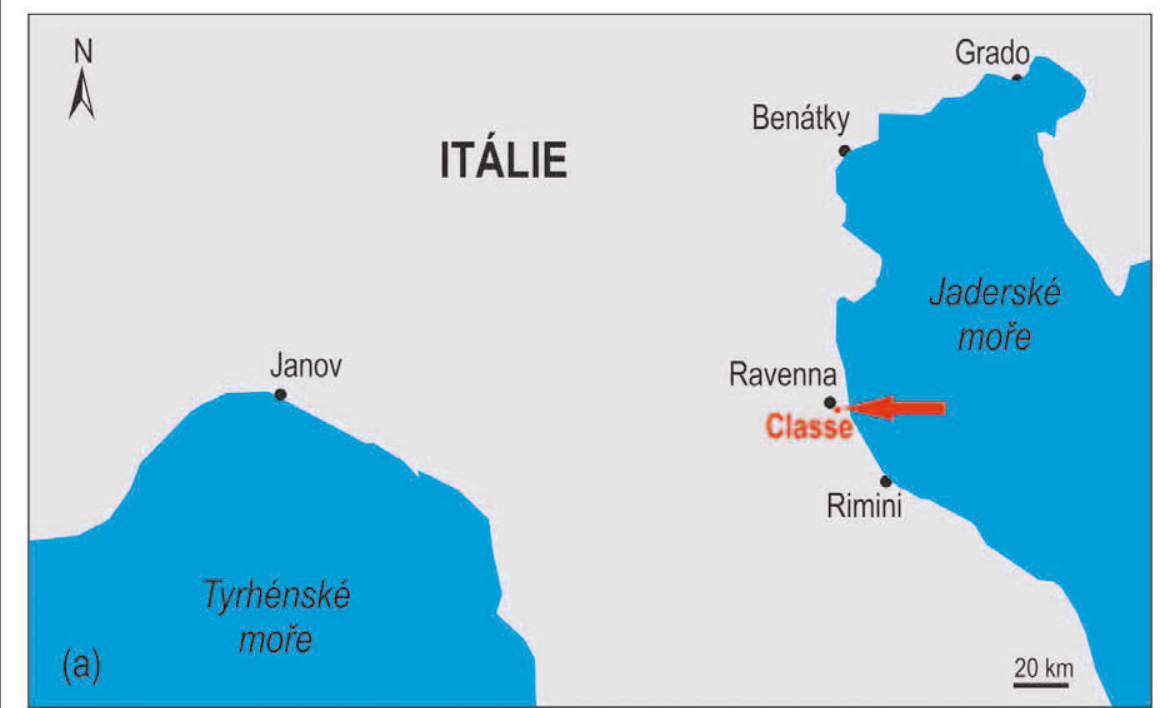

(b)

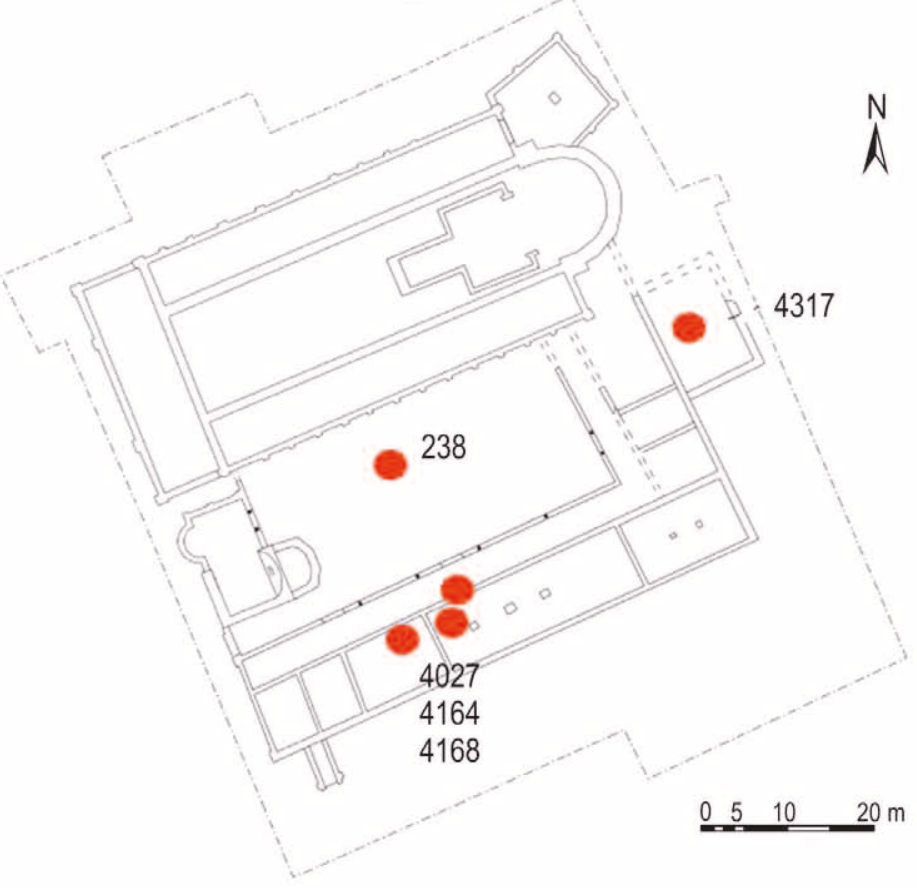

Obr. 1: (a) Schematická mapa regionu v okolí Ravenny, (Itálie), červená šipka označuje pozici Classe; (b) církevní komplex San Severo v Classe: basilika s přilehlým klášterem a dvěma mauzolei, situace na přelomu 9. a 10. stol., podle Augenti et al. 2012.

Fig. 1: (a) Schematic map of the region around the city of Ravenna (Italy), the red arrow indicates the position of Classe; (b) ecclesiastical complex of San Severo: the Basilica with the adjacent monastery and two mausoleums, situation at the turn of the $9^{\text {th }}$ and $10^{\text {th }}$ centuries, according to Augenti et al. 2012.

literatuře jako materiál uváděn prokonnéský mramor, př́ípadně pouze označení „východní“ mramor (Tůmová 2013), vyplynuly četné analogie. Analogie byly shledány rovněž na mramorových artefaktech uložených nyní $\mathrm{v}$ ravennských a dalších severoitalských muzeích, např. v muzeu opatství Abbazia di Pomposa (Tůmová 2013).

Záměrem tohoto článku je navázat na předchozí česko-italský výzkum, $\mathrm{v}$ rámci něhož byly podrobeny analýzám tři vybrané vzorky bílého mramoru z lokality San Severo v Classe, přičemž výsledky ukazovaly na rozdílnou provenienci vzorků. U vzorku č. 67 byla potvrzena provenience z ostrova Proconnesos. U obou zbývajících vzorků (č. 256 a 263) byla potvrzena odlišná zdrojová lokalita: nebyla sice vyloučena provenience $\mathrm{z}$ ostrova Proconnesos, avšak muselo by se jednat o jiný těžební distrikt než tomu bylo u vzorku č. 67. V úvahu dále připadaly lokality Muğla (Iasos, Göktepe) v dnešním jihozápadním Turecku (antické Kárii), nebo Balikesir v Marmarském regionu $\mathrm{v}$ dnešním Turecku (Tůmová et al. 2016). $Z$ uvedeného vyplývá, že počet analyzovaných vzorků je třeba rozširíit.

\section{Historický význam Ravenny a př́istavu Classe v pozdní antice}

Význam Ravenny vzrostl poté, kdy si ji západořímský císař Honorius zvolil za své sídelní město: císařský dvůr do ní přesídlil z Mediolana (dnešního Milána) v roce 402. Ravenna tak prakticky ze dne na den získala statut sedes imperialis a její význam vzrostl nejen $\mathrm{z}$ hlediska administrativně-správního, ale také obchodního a kulturního, a to zejména díky kontaktům s Konstantinopolí, hlavním městem východní části římské ŕíše. Classe jako hlavní prístav Ravenny predstavoval v 5 . a 6. stol. n. l. významné centrum lokálního i dálkového obchodu a distribuce zboží, směřujícího do Ravenny ze vzdálených středomořských lokalit, mramor - at již v podobě prefabrikovaných či hotových výrobků (sarkofágy, architektonické dekorace) - nevyjímaje. Aktivita dálkového obchodu byla jedním z pilírů ekonomické prosperity Ravenny a celého přilehlého regionu. Historie Ravenny je podrobněji popsána ve-príloze 1.

\section{Archeologická lokalita San Severo v Classe}

Pozdně antická basilika sv. Severa v Classe, jež se nacházela poblíž hlavního přístavu, výrobního okrsku a skladů, intra muros, tj. uvnitř městských hradeb (Augenti et al. 2012), byla postavena v 2. pol. 6. stol., jak dokládají mimo jiné i nálezy keramiky (Augenti 2017), 


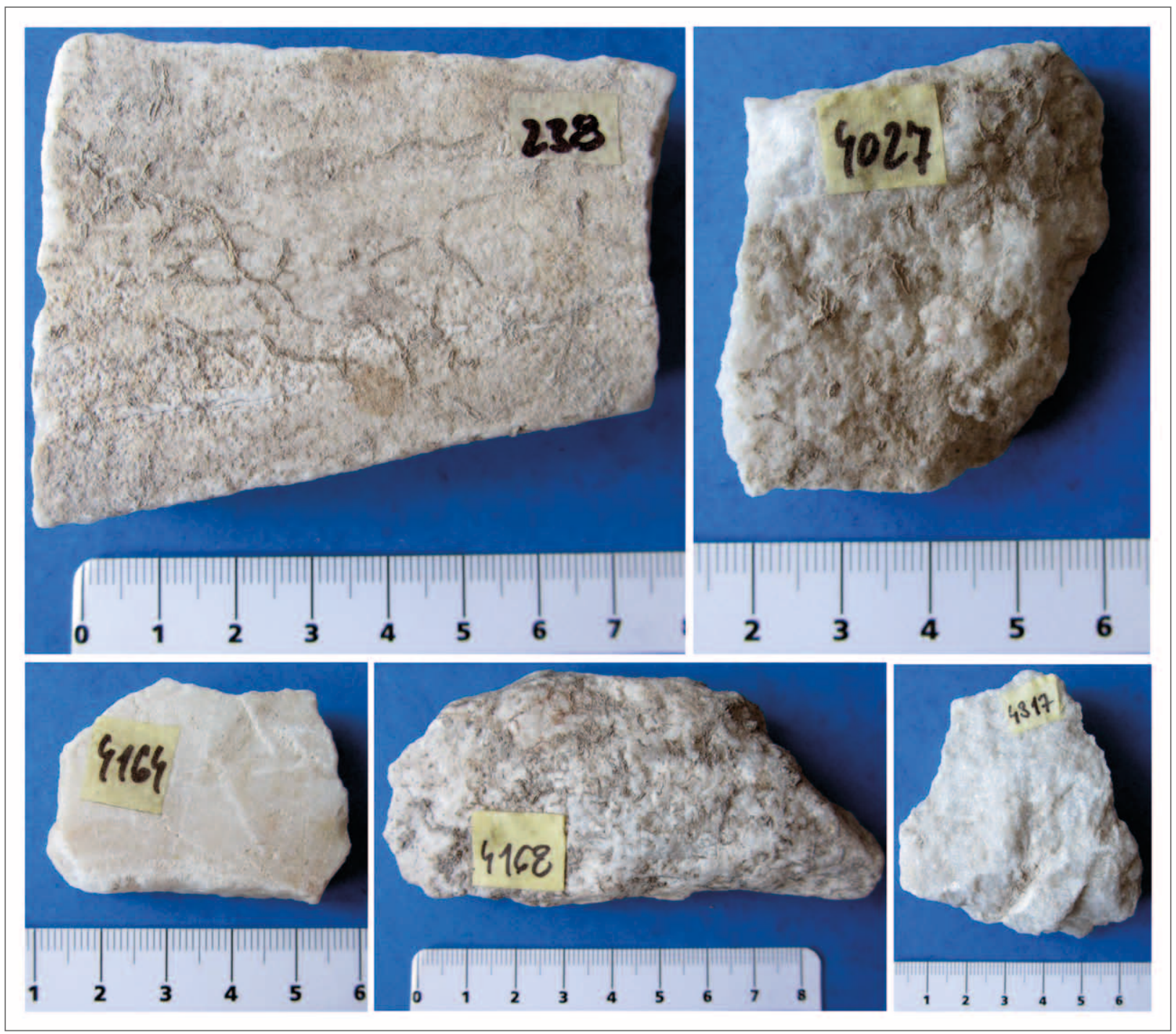

Obr. 2: Fotografie analyzovaných vzorků mramoru č. 238, 4027, 4164, 4168 a 4317.

Fig. 2: Photography of analyzed marble samples $N^{\circ} 238,4027,4164,4168$ and 4317.

a to jako poslední velký stavební (církevní) záměr v této oblasti, v bezprostřední blízkosti místa, kde byly uloženy ostatky ravennského mučedníka svatého Severa a kde bylo v 5. stol. postaveno první sacellum (Christie 2017). Jak vyplývá z písemných pramenů a nálezů keramiky (Augenti et al. 2012; Augenti 2017), na konci 9. stol., nejpozději však v polovině 10. stol. byl u basiliky založen benediktinský klášter, jenž v následujících staletích prodělal několik větších přestaveb (např. v roce 1285) i řadu menších stavebních zásahů, jak dokládá komplexní stratigrafie struktur odkrytých během archeologického výzkumu (Augenti, Laszlovszky 2007). Přibližně od poloviny 15. stol. však byly klášterní budovy opouštěny a posléze sloužily jako zdroj levného a dostupného materiálu pro stavební záměry nejen v okolí, ale i v dalších sídlech severovýchodní Itálie (Augenti et al. 2012). Poslední řeholníci opustili klášterní budovy v roce 1512 (Christie 2017). Sekundární využívání (spoliatio) materiálu (např. cihel či mramorových artefaktů, zejména architektonických prvků jako jsou patky, dříky, hlavice sloupů apod.) tak provázelo církevní komplex San Severo od jeho počátků až po samý konec jeho existence (Tůmová, Cirelli 2019). Rekonstrukcí a přestaveb však nebyla ušetřena ani basilika, poslední větší přestavbu zaznamenala v polovině 18. stol.; zbytky basiliky pak byly rozebrány ve 20. letech 19 . stol. (Farioli 1983). V současnosti již nad terén vystupují pouze zbytky zdí zvonice.

\section{Materiál}

Za účelem provedení mineralogicko-petrografických a geochemických analýz bylo vybráno dalších pět vzorků bílo-šedého mramoru, pocházejících z prostor kláštera San Severo v Classe (obr. 1 b). Většina kamenných artefaktů, odkrytých během archeologických kampaní v letech 2007-2011, byla nalezena ve vrstvách klášterního komplexu datovaných do období od 12. do 15. stol. Vybrané vzorky (obr. 2). pocházejí z vrstev datovaných od 11. do 15. stol. (v 15. stol. již začínají klášterní budovy chátrat). Skupina bílo-šedého mramoru byla na základě makroskopicky pozorovatelných kvalit (zejména zrnitost, přítomnost šedého žilkování) dále rozdělena do několika podskupin (Tůmová 2013). Tyto kvality však nepředstavují diskriminační hledisko pro určení provenience. Pro 
vzorkování za účelem provedení analýz je proto uvažován soubor bílo-šedého mramoru jako jeden celek.

Z makroskopického hlediska náleží čtyři z analyzovaných vzorků bílo-šedého mramoru (č. 4027, 4168, 4317, 238) do nejpočetněji zastoupené skupiny bílo-šedého hrubozrnného mramoru. Vzorky č. 4027, 4168 a 4317 mají šedé žilkování; vzorek č. 238 je bez šedého žilkování. Vzorek č. 4164 náleží do méně početné skupiny jemnozrnného bílého mramoru.

Vzorky byly vybrány podle následujících parametrů: (a) reprezentují jednotlivé kategorie bílého, resp. bílo-šedého mramoru (dle makroskopického pozorování) nalezeného na lokalitě San Severo; (b) pokrývají široké období existence klášterního komplexu od 11. do 15. stol., zejména období vrcholného středověku, a to až do fáze opouštění klášterních budov v 15. stol.; (c) pocházejí ze sektorů, v nichž bylo při archeologických výzkumech 2006-2011 nalezeno největší množství kamenných artefaktů či fragmentů, a to zejména bílého mramoru (vnitřní - rajský - dvůr, kuchyně / refektářr, kapitulní síň).

Vzorek č. 4317 pochází z vrstvy 23031, datované do 13.-14. stol. a náležející do sektoru 23000 - kapitulní síně, odpovídajícího ploše o rozloze přibližně $120 \mathrm{~m}^{2}$. Archeologický výzkum prokázal mnoho zásahů tzv. spoliatio - zásahů do původních struktur kvůli následnému (sekundárnímu) využití materiálu, zejména kamenného (Augenti et al. 2012). V prostoru kapitulní síně byla $\mathrm{v}$ průběhu archeologického výzkumu zjištěna přítomnost př́pravné fáze podlahy v podobě silné vrstvy malty z 11. stol., do níž měly být pravděpodobně uloženy mramorové desky či podlaha opus sectile, o čemž svědčí četné nálezy mramorových fragmentů. Tato podlaha byla ve 14. stol. vyvýšena (Augenti et al. 2012). Jedná se o neopracovaný, amorfní fragment bílého hrubozrnného mramoru s výskytem nepravidelně rozesetých šedých skvrn.

Vzorky č. 4027, 4164 a 4168 pocházejí ze sektoru 14000 - kuchyně, refektáře a vnějšího dvora, nacházejícího se v jižní části klášterního komplexu. Archeologický výzkum prokázal několik fází existence těchto budov (kuchyně, refektář) v průběhu vrcholného středověku, jejich zánik pak v 15. stol., kdy docházelo k masivnímu rozebírání (spoliatio) zejména kamenných prvků (Augenti et al. 2012). Vzorek č. 4027 byl nalezen ve vrstvě 14165, datované do 11.-12. stol. Jedná se o neopracovaný fragment bílo-šedého, hrubozrnného mramoru s výskytem šedých, nepravidelně rozesetých skvrn. Vzorek č. 4164 pochází z vrstvy 14134, datované do 12. stol. Jedná se o opracovaný fragment desky (mocnost $0,8 \mathrm{~cm}$ ) bílo-šedého, jemnozrnného mramoru bez okem viditelných šedých žilek či skvrn. Vzorek č. 4168 pochází z vrstvy 14140, datované do 13.-14. stol. Jedná se o neopracovaný fragment bílo-šedého, hrubozrnného mramoru s výskytem šedých, paralelně uspořádaných žilek.

Vzorek č. 238 pochází ze sektoru 18000 - rajského (vnitřního) dvora kláštera. Klášterní dvůr čtvercového půdorysu byl vybudován současně s ostatními budovami v době založení kláštera (9.-10. stol.); klášterní zahrada uprostřed byla po obvodu lemována portikem: in situ se dochovalo několik mramorových patek sloupů, archeologicky doloženy jsou rovněž stopy po tzv. spoliatio (Augenti et al. 2012). Vzorek byl nalezen ve vrstvě 18006, datované do konce 15. stol. Jedná se o opracovaný fragment desky (mocnost 1,6 cm) bílo-šedého, hrubozrnného mramoru bez makroskopicky viditelných šedých žilek či skvrn.

\section{Metodika}

Vzorky byly podrobeny analýzám metodami optické polarizační mikroskopie (PLM), skenovací elektronové mikroskopie a mikroanalýzy (SEM/EDS/WDS) na Ústavu geologických věd PřF MU a v Centru dopravního výzkumu, v.v.i. a práškové rtg-difraktometrie (XRD) na Ústavu geologických věd PřF MU (viz e-příloha 2). $\mathrm{V}$ odboru environmentální geochemie a biogeochemie České geologické služby, oddělení stabilních izotopů, bylo provedeno stanovení stabilních izotopů $\delta^{13} \mathrm{C}$ a $\delta^{18} \mathrm{O}$. Výsledky analýz byly srovnány s údaji referenčních databází

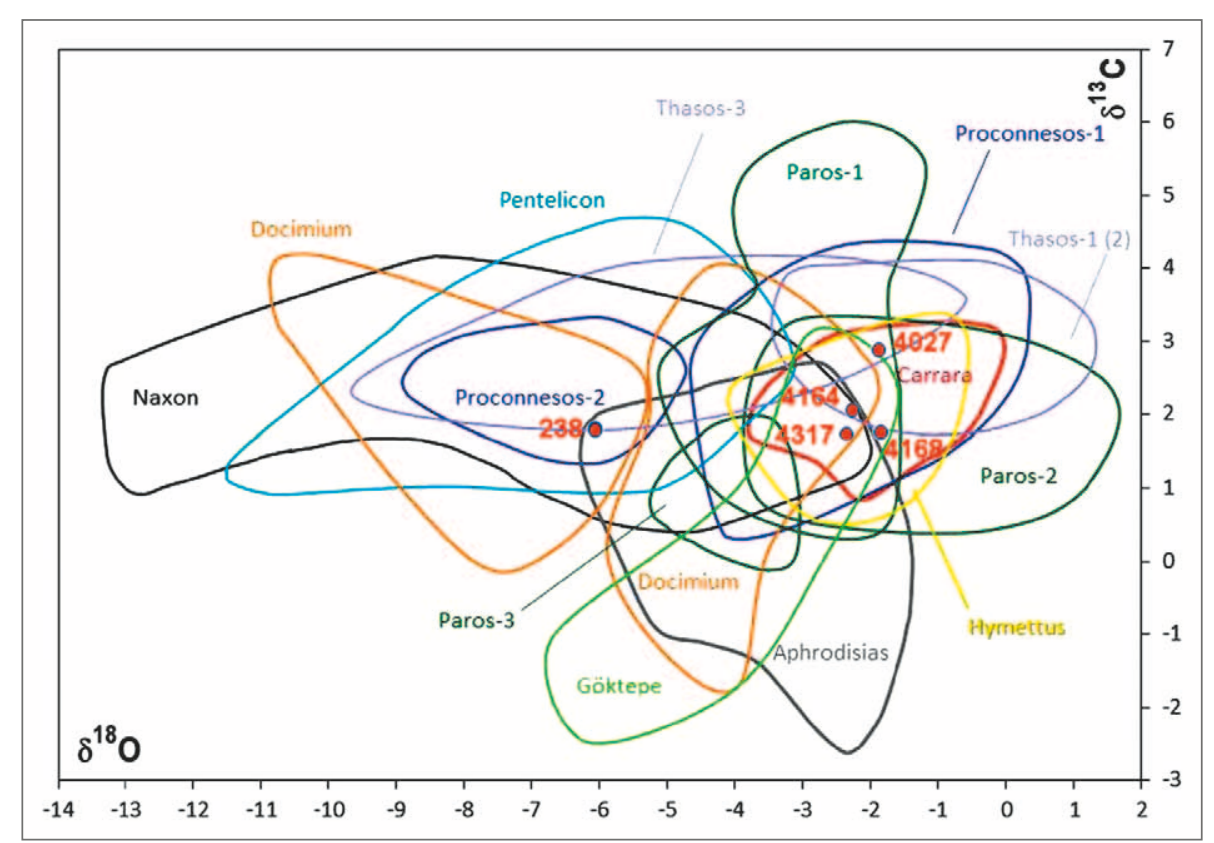

Obr. 3: Diagram s vynesenými hodnotami $\delta^{13} \mathrm{C}$ vs. $\delta^{18} \mathrm{O}$ izotopického složení analyzovaných vzorků mramoru ve vztahu k možným zdrojovým lokalitám z referenční databáze, publikované Antonellim a Lazzarinim (2015).

Fig. 3: Diagram with plotted $\delta^{13} \mathrm{C}$ vs. $\delta^{18} \mathrm{O}$ values of the isotopic composition of the analyzed marble samples in relation to possible source localities from the reference database, published by Antonelli and Lazzarini (2015). 
středomořských mramorů, těžených v antice. Podrobný popis metodiky je uveden v e-př́loze 3.

\section{Výsledky \\ Stanovení stabilních izotop ${ }^{13} \delta^{13}$ a $\delta^{18} \mathrm{O}$}

Výsledky stanovení zastoupení stabilních izotopů $\delta^{13} \mathrm{C}$ a $\delta^{18} \mathrm{O}$ vynesené do grafu Antonelliho a Lazzariniho (2015) jsou uvedeny na obrázku 3, numerické hodnoty v e-příloze 4 . Vzorek 238 odpovídá polím Proconnesos-2, Docimium, Naxos a Pentelicon a zároveň je na hranicích polí Thasos-3 a Afrodisias. Pozice ostatních studovaných vzorků je podobně komplikovaná: všechny čtyři spadají zároveň do polí Proconnesos-1, Carrara, Paros-1, Paros-2, Hymettus, a Göktepe, ale samostatně je možné je přiřadit několika dalším polím nebo jejich hranicím. Všech pět analyzovaných vzorků tedy v Antonelliho a Lazzariniho diagramu zároveň spadá pouze do polí lokality Proconnesos-1 nebo Proconnesos-2.

\section{Minerální složení}

Všechny studované vzorky představují bílo-šedé kalcitické mramory s nízkým obsahem dolomitu. Dolomit tvoří ve studovaných vzorcích izolované oblasti (e-příloha 5). Nejvyšší obsah dolomitu byl identifikován ve vzorcích $238(5,2 \mathrm{hm}$. \%) a 4317 (1,4\%; zde je př́tomen i ankerit, který ve zbytku série v množství detekovatelném pomocí XRD chybí; pomocí SEM/EDS byl ankerit zjištěn rovněž ve vzorku 4027), v ostatních vzorcích zastoupení dolomitu nepřesahuje $1 \%$. Ve všech vzorcích je přítomen křemen v obsazích nepřekračujících první desetiny procenta. Vzorek 4164 se od ostatních odlišuje relativně vysokým zastoupením slíd, jedná se především o flogopit (e-přílohy 5 a 6) a prítomností jílových minerálů a chloritu. Pomocí XRD je při takto nízkých obsazích obtížné navzájem odlišit jednotlivé minerály se slídovou strukturou. Proto není možné vyloučit ani př́tomnost illitu. Lze předpokládat, že chlorit je produktem alterace flogopitu. Ve vzorcích 4027 a 4317, kromě křemene, žádné další nekarbonátové minerály pomocí XRD identifikovány nebyly. Výsledky kvantitativní fázové analýzy jsou uvedeny v tabulce 1 . Pomocí XRD nelze v polyfázových vzorcích spolehlivě navzájem rozlišit většinu slídových minerálů, proto jsou tyto fáze $\mathrm{v}$ tabulce 1 uvedeny souborně jako minerály se slídovou strukturou. Detailní identifikace byla provedena pomocí skenovací elektronové mikrosopie a mikroanalýzy.

Tab. 1: Výsledky XRD kvantitativní fázové analýzy v hm. \%, zaokrouhleno na jedno desetinné číslo.

Tab. 1: Results of XRD quantitative phase analysis in wt. \%, rounded to one decimal place.

\begin{tabular}{|l|c|c|c|c|c|}
\hline Vzorek/minerál & $\mathbf{2 3 8}$ & $\mathbf{4 0 2 7}$ & $\mathbf{4 1 6 4}$ & $\mathbf{4 1 6 8}$ & $\mathbf{4 3 1 7}$ \\
\hline Kalcit & 94,6 & 99,2 & 97,5 & 99,2 & 98,2 \\
\hline Dolomit & 5,2 & 0,6 & 0,5 & 0,7 & 1,4 \\
\hline Křemen & 0,2 & 0,2 & 0,2 & 0,1 & 0,3 \\
\hline Minerály se slídovou strukturou & 0,1 & 0 & 1,1 & 0 & 0,1 \\
\hline Kaolinit & 0 & 0 & 0,6 & 0 & 0 \\
\hline Chlorit & 0 & 0 & 0,5 & 0 & 0 \\
\hline
\end{tabular}

Akcesorické minerály, některé z nich v obsazích pod mezí detekce XRD, byly identifikovány pomocí SEM/EDS/ WDS. Jedná se o apatit, sulfidy (pyrit, sfalerit), titanit, některý z polymorfů $\mathrm{TiO}_{2}$, zirkon a fluorit. Přehled asociací akcesorických minerálů v jednotlivých vzorcích je uveden v e-příloze 5. Přepočtené výsledky chemického složení stanoveného pomocí WDS umožňující přesnou klasifikaci slídových minerálů, chloritu a apatitu jsou uvedeny v e-příloze 6, vynesení výsledků pro slídy do klasifikačního diagramu dle Tischendorfa (1997) - viz e-př́loha 7. Slídy byly identifikovány jako muskovit a flogopit, chlorit jako klinochlor. Dále byl proveden přepočet chemického složení kalcitu a dolomitu (e-př́loha $8 \mathrm{a}-\mathrm{d}$ ). Poměr $\mathrm{Ca} / \mathrm{Si}$ se $\mathrm{v}$ dolomitu pohybuje v rozmezí 1,01-1,12. Kalcit ve všech studovaných vzorcích obsahuje hořčík v množství 0,01-0,04 apfu (atomů na vzorcovou jednotku minerálu).

\section{Mikrostruktura}

Vzorky 4164 a 283 reprezentují jemnozrnný mramor, zatímco ostatní vzorky jsou mramory hrubozrnné (obr. 4). Kromě rozdílů v maximální velikosti zrn (MGS) je nápadný výrazně menší rozptyl velikostí zrn u vzorků 238 a 4164, které vykazují nižší hodnotou MGS (obr. 5).

Maximální velikost zrn karbonátových minerálů (MGS) byla srovnána s daty Antonelliho a Lazzariniho (2015), obr. 5. U vzorků 4027, 4168 a 4317 byla shodně stanovena hodnota $2,25 \mathrm{~mm}$, která odpovídá mediánu lokality Proconnesos a je blízká mediánům lokalit Paros-2(3) a Afrodisias. Vzorky 238 a 4164 jsou jemnozrnnější, MGS u nich dosahuje 0,85 a $0,65 \mathrm{~mm}$. Dolní mez MGS pro Proconnesos dle Antonelliho a Lazzariniho (2015) dosahuje $0,65 \mathrm{~mm}$. V př́padě této provenience by se MGS vzorků 238 a 4164 pohybovala blízko dolní hranice odlehlých hodnot pro Proconnesos, respektive zcela na ní. Hodnota vzorku 238 je nejblíže mediánům lokalit Docimium, Pentelicon, hodnota vzorku 4164 mediánům lokalit Göktepe a Hymettus (obr. 5).

Petrografická charakteristika studovaných vzorků je přehledně uvedena v e-př́loze 5 , tab. 1/5.

\section{Diskuze}

Mramor z ravennských basilik (zejména sarkofágy, architektonická dekorace) je ve starší literatuře obvykle označován jako „bílý“, př́ípadně „,̌ecký“, čímž je bez další konkretizace naznačen predpoklad jeho provenience (Farioli 1969; Martinelli 1968; Valenti Zucchini, Bucci 1968). Nechybí nicméně ani zmínky o přítomnosti prokonnéského mramoru (Rizzardi 2016). Klasifikace „prokonnéský mramor“však zpravidla vychází z typologického srovnání s produkty „sériové “ výroby v antických prokonnéských lomech (především typické tvarosloví hlavic, dříků a patek sloupů) a ze stylistického rozboru importovaných artefaktů, zejména sarkofágů, jejichž styl a vysoká kvalita provedení evokovala hypotézu, že se jedná o importy z Konstantinopole (Rizzardi 2016) a v neposlední řadě pak z historických zmínek o původu mramoru konkrétního artefaktu: prokonnéský mramor zmiňuje v několika př́padech ve svém díle Liber pontificalis Ecclesiae Ravennatis ravennský protohistorik z 9. stol. Andreas Agnellus 


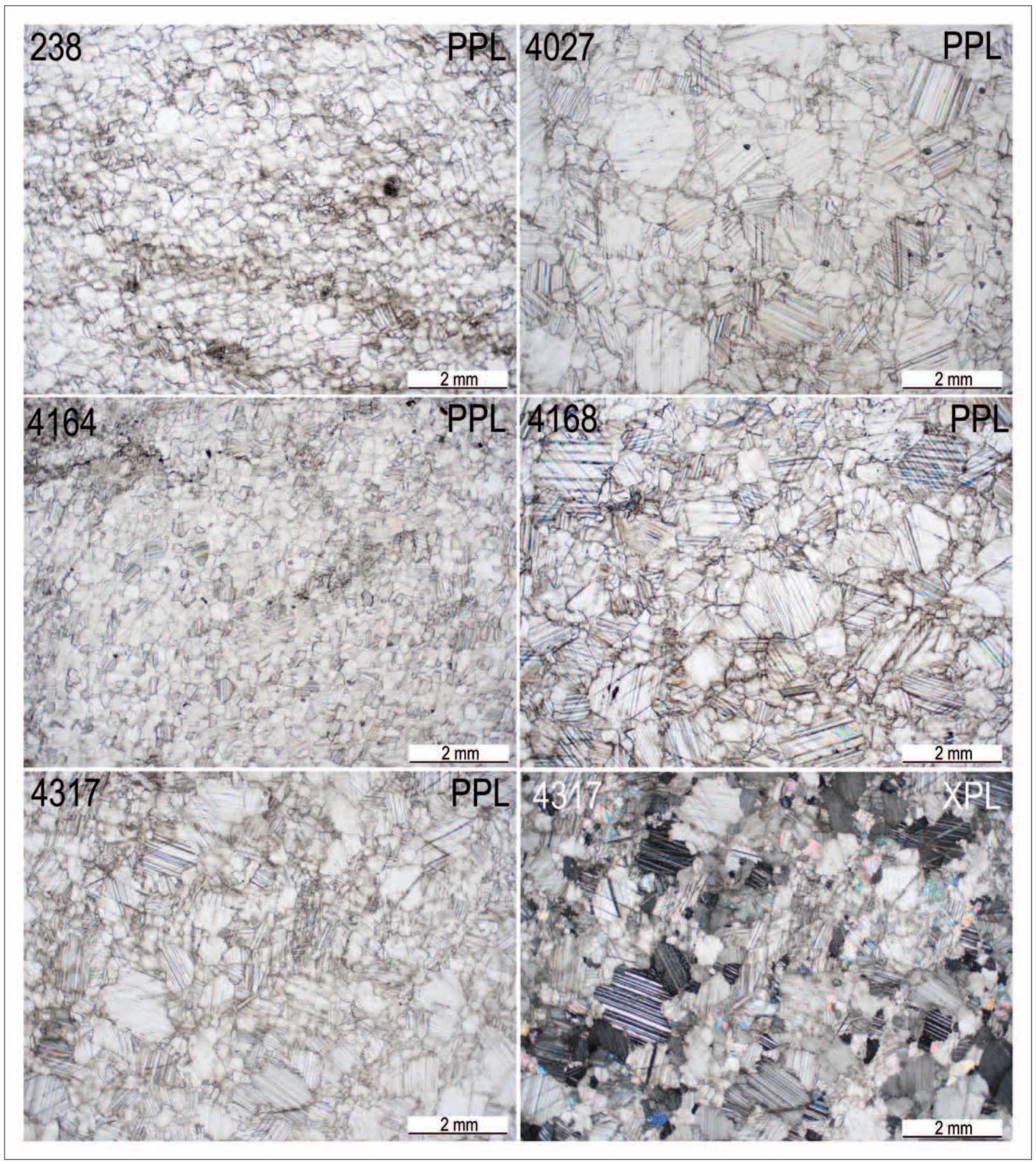

Obr. 4: Srovnání mikrostruktury studovaných vzorků ( $\mathrm{PPL}=$ lineárně polarizované světlo, XPL = př́ičně polarizované světlo). Vzorky 238 a 4164 představují jemnozrnné, ostatní vzorky hrubozrnné, mramory.

Fig. 4: Comparison of the microstructure of studied samples; (PPL = plane polarized light, XPL = cross polarized light). Samples 238 and 4164 represent fine-grained, the other samples coarse-grained marbles.

(LPR L, LPR LXXVI, LPR XXVI). Orientaci obchodních kontaktů Ravenny zejména na jižní a východní oblasti antického Stř̌edomoří dokládá jak přítomnost dalších litotypů, které byly identifikovány na lokalitě San Severo v Classe: Asia Minor, pevninské Řecko a Egejské ostrovy, méně severní Afrika a Španělsko (Tůmová 2013), tak i nálezy keramiky, zejména transportních amfor (Augenti, Cirelli 2010).

Obecně se tedy předpokládá, že byl do Ravenny v 5. a 6. stol. importován mramor zejména $z$ ostrova
Proconnesos (dnešní Marmara v Turecku), jenž byl v antice oblíbený (hojně začíná být využíván od 2. poloviny 1. stol., viz Attanasio et al. 2008; Moropoulou et al. 2019) nejen pro své kvality a dekorativní charakter v podobě šedého žilkování (srov. Amadori et al. 1998), které dokázali antičtí kameníci mistrně využít, ale i pro svou ekonomickou výhodnost, jak vyplývá ze srovnání cen jednotlivých mramorů uvedených v Diokleciánově Ediktu o maximálních cenách (Edictum de maximis pretiis), vydaného roku 301 (Cameron 1993), a v neposlední řadě 


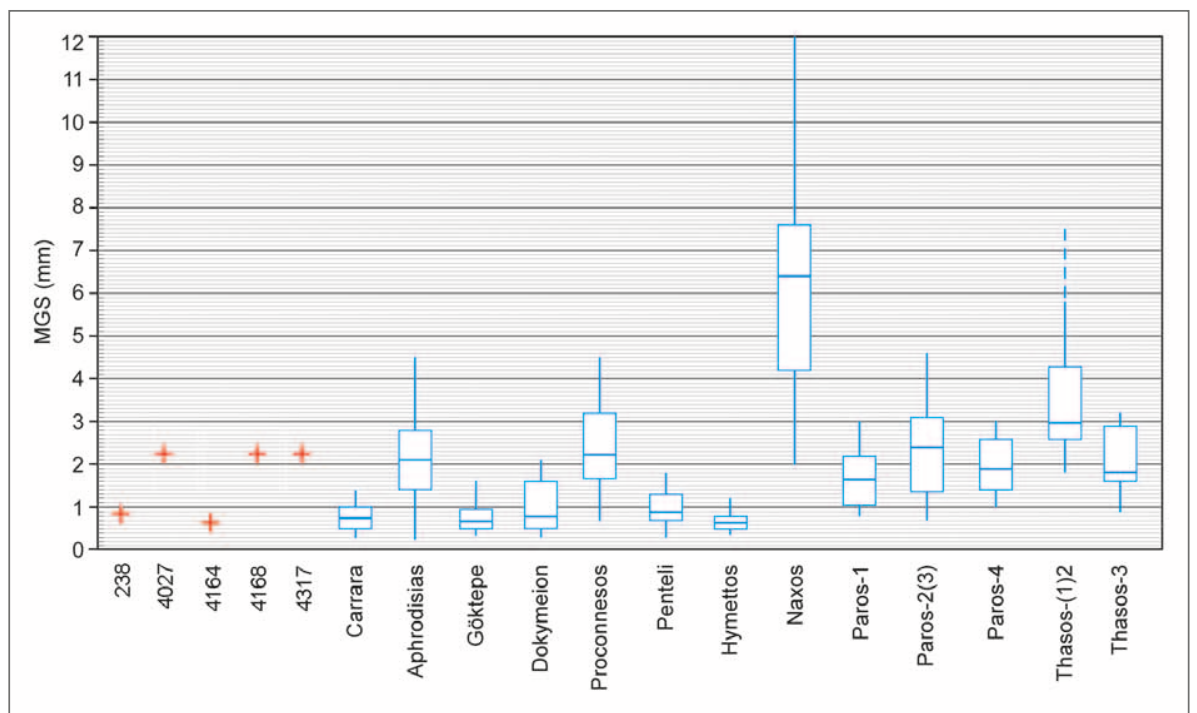

Obr. 5: Maximální velikost zrn kalcitu (dolomitu) - srovnání s diagramem pro středomořské mramory z publikace Antonelli a Lazzarini (2015).

Fig. 5: Maximum grain size (MGS) of calcite/dolomit - comparison with the diagram for Mediterranean marbles according to Antonelli and Lazzarini (2015).

i dopravní dostupnost (většina lomů se nacházela u severního pobřeží ostrova Proconnesos, tj. v blízkosti př́istavu).

Vzhledem ke zmiňovaným historickým okolnostem, které vedly $\mathrm{k}$ postupnému utichání obchodní aktivity př́stavu v Classe zejména v 8. stol., lze předpokládat, že masivní import mramoru do Ravenny můžeme časově zařadit přibližně do období od počátku 5. stol. do konce 7. stol., tedy do období pozdní antiky a současně do doby největšího rozmachu prrístavu v Classe (srov. Augenti 2017) s tím, že ani před rokem 402 není vyloučen import mramoru i ze vzdálenějších středomořských lokalit zejména s ohledem na skutečnost, že v bezprostřední blízkosti Ravenny se nenacházejí žádné lomy na mramor (karrarský mramor se přestává využívat v průběhu 3. stol.). Lze však předpokládat, že před usídlením císařského dvora v Ravenně byla poptávka po nákladném materiálu, jakým mramor bezesporu byl, podstatně skromnější. Díky existenci ravennského př́stavu byl umožněn zámořský obchod, díky kanálu Fossa Augusta rovněž říční spojení po Pádu s ostatními regiony severní Itálie.

Mramor, $\mathrm{z}$ něhož jsou vyrobeny artefakty okruhu ravennského umění 5. a 6. stol. (sarkofágy, cancelli, architektonické články a dekorace), jimž je často přisuzována provenience z ostrova Proconnesos, by bylo možné popsat jako bílý až bílo-šedý, hrubozrnný, často s přítomností výrazného šedého žilkování (dle řezu kamene bud'v horizontálním kladu či v podobě nepravidelných skvrn). Tyto kvality sice patří mezi charakteristiky prokonnéského mramoru, nikoli však výlučně, nebot podobné vlastnosti nalézáme např̀. u thaského mramoru (Amadori et al. 1998) a u dalších středomořských mramorů, např. u bílé variety mramoru z lokality Muğla (Göktepe). Výrazné paralelní žilkování ve spojitosti s hrubozrnností je však jednou z (makroskopických) charakteristik prokonnéského mramoru a poskytuje tak minimálně vodítko k určení provenience (srov. Antonelli, Lazzarini 2015). Mezi různými varietami prokonnéského mramoru však můžeme sporadicky nalézt rovněž jemnozrnný mramor (MGS dle Attanasia menší než $1 \mathrm{~mm}$ ), a to zejména v západní části ostrova, např. na lokalitách Altintaş, Mandira, Suleyman (Attanasio et al. 2006; Attanasio et al. 2008).

Pro spolehlivější určení provenience mramoru je nezbytné podrobit vybrané vzorky kombinaci mineralogických, petrografických a geochemických analýz a srovnat výsledky s referenčními databázemi středomořských mramorů, těžených v antice (srov. Antonelli et al. 2016), nebot' makroskopická hlediska nepředstavují diskriminační faktory pro navržení provenience bílých mramorů. Díky nedávnému rozsáhlému vzorkování D. Attanasia, M. Brilliho a M. Bruna, v rámci něhož bylo analyzováno 397 vzorků mramoru z většiny lokalit, na nichž probíhala těžba $\mathrm{v}$ antice, a rovněž $\mathrm{z}$ moderních lomů na ostrově Marmara, je nyní k dispozici referenční databáze nejrůznějších variet prokonnéského mramoru (Attanasio et al. 2008). Data o prŕtomnosti akcesorických minerálů ve vzorcích ze zdrojových lokalit však dosud nelze považovat za dostatečná.

\section{Vzorek 238}

Na základě poměrů obsahů stabilních izotopů $\delta^{13} \mathrm{C}$ a $\delta^{18} \mathrm{O}$ (viz obr. 3 a e-př́loha 4) a hodnot MGS (obr. 5) lze u vzorku 238 usuzovat na zdrojové lokality Docimium (Îscehisar u Afyonu v Turecku) nebo Pentelicon, nejsou však vyloučeny ani lokality Proconnesos, Thasos 3 a Afrodisias (stanovená hodnota MGS je pro tyto lokality hraniční). Obsah dolomitu je zde relativně vysoký, 5,2\%. Identifikované akcesorické minerály u vzorku 238 jsou křemen, muskovit, flogopit, apatit, pyrit, některý z polymorfů $\mathrm{TiO}_{2}$. Apatit nelze nicméně považovat za diskriminační faktor, nebot' je obsažen u většiny hlavních zdrojových lokalit stř̌edomořských mramorů, těžených v antice (Capedri, Venturelli 2004). Křemen je jako indikátor provenience využitelný pouze obtížně, protože jako akcesorie se vyskytuje ve většině karbonátových hornin včetně mramoru. Antonelli a Lazzarini (2015) uvádějí flogopit jako charakteristickou akcesorii pro lokalitu Proconnesos. Vzhledem $\mathrm{k}$ př́tomnosti flogopitu ve vzorku 238 lze předpokládat jeho původ $z$ Proconnesu a to i přesto, že hodnota MGS je na dolní hranici rozptylu pro tuto lokalitu. Flogopit se vyskytuje i v thaském mramoru, který však neobsahuje dolomit (Capedri et al. 2004), jenž je ve vzorku 238 obsažen, a to dokonce $\mathrm{v}$ množství nad $5 \mathrm{hm}$. \%, čímž lze provenienci z Thasu vyloučit. Rovněž oxidy titanu, obsažené ve vzorku, se vyskytují u prokonnéského mramoru 
(srov. Capedri, Venturelli 2004). Provenience vzorku 238 je tedy s největší pravděpodobností Proconnesos, resp. Proconnesos 2, což je méně častá varieta prokonnéského mramoru, lokalizovaná do oblasti východního Çamliku v okolí Aksoy (Attanasio, Brilli, Bruno 2008).

\section{Vzorek 4164}

Kombinace hodnot stabilních izotopů $\delta^{13} \mathrm{C}$ a $\delta^{18} \mathrm{O}$ (viz obr. 3 a e-příloha 4) a MGS (obr. 5) vylučuje u vzorku 4164 provenienci z Prokonnésu. V úvahu připadají zejména lokality Hymettus, Göktepe (Muğla), nebo Docimium, není vyloučena lokalita Afrodisias (MGS na hranici pole). Identifikované akcesorické minerály jsou u vzorku 4164 flogopit, chlorit, apatit, zirkon, $\mathrm{TiO}_{2}$, kaolinit. Z hlediska př́tomnosti akcesorických minerálů (zejména př́tomnost chloritu) by bylo možné u tohoto vzorku usuzovat na nejpravděpodobnější zdrojovou lokalitu Docimium, nebot' chlorit je typický právě pro tuto oblast (Antonelli a Lazarini, 2015) a obsahy stabilních izotopů $\delta^{13} \mathrm{C}$ a $\delta^{18} \mathrm{O}$ i MGS jí rovněž odpovídají. Zöldföldi, Satir (2003) však ve vzorcích mramoru z lokality Afyon (Docimium) chlorit neindikují, naproti tomu je indikován u mramoru pocházejícího z lokality Muğla (tamtéž). Antonelli a Lazarini (2015) uvádějí chlorit jako charakteristý akcesorický minerál mramoru z oblasti Docimium (dnešní Turecko). Chlorit je dle Antonelliho a Lazzariniho (2015) typický rovněž pro pentelský mramor a pro dolomitickou varietu thaského mramoru (srov. Capedri, Venturelli 2004). Lokality Pentelicum a Thasos však u tohoto vzorku vylučují bud' hodnoty stabilních izotopů $\delta^{13} \mathrm{C}$ a $\delta^{18} \mathrm{O}$ nebo MGS. Vzorek 4164 nicméně obsahuje také flogopit, typický zejména pro prokonnéský mramor - provenienci z Prokonnésu však neodpovídají hodnoty MGS. Př́ítomnost, či naopak absence akcesorií však není samostatným diskriminačním faktorem, je vždy třeba uvažovat v souvislosti s ostatními naměřenými hodnotami, zejména hodnot stabilních izotopů $\delta^{13} \mathrm{C}$ a $\delta^{18} \mathrm{O}$ a MGS. Obsahy akcesorií se rovněž mohou lišit v závislosti na konkrétní části vzorku, použité pro provedení analýz (srov. Zöldföldi, Satir 2003). Vzorek neobsahuje plagioklas, jenž je uváděn jako charakteristický akcesorický minerál pro mramory z Afrodisias (Antonelli, Lazzarini 2015). Z hlediska mikrostruktury lze vzorek 4164 přirovnat $\mathrm{k}$ mramoru z lokality Muğla - Göktepe (Antonelli, Lazzarini 2015). Z výše uvedeného vyplývá, že provenience tohoto vzorku není zcela jednoznačná, nicméně lokality Göktepe (Muğla), prŕípadně Docimium, se jeví jako nejpravděpodobnější z uvažovaných lokalit.

Skupina tří vzorků $(4027,4168,4317)$ vykazuje podobné hodnoty stabilních izotopů $\delta^{13} \mathrm{C}$ a $\delta^{18} \mathrm{O}$ a identické hodnoty MGS. U vzorku 4027 připadají v úvahu zejména lokality Proconnesos (1), Paros-2 a Thasos 3. U vzorku 4168 lokality Proconnesos (1), nebo Paros-2 a u vzorku 4317 lokality Proconnesos (1), Paros-1, Paros-2, Afrodisias, případně Naxos. Průnik hodnot všech tří vzorků ukazuje bud' na provenienci z Prokonnésu, nebo z Paru (zejména Paros-2). Prochaska, Attanasio (2012) i Attanasio, Brilli, Bruno (2008) zmiňují úskalí problematické diskriminace mezi prokonnéským a parským mramorem (zejména varieta Paros-2). Capedri, Venturelli (2004) uvádějí absenci dolomitu v parském mramoru. Všechny tř̌i vzorky vykazují obsah dolomitu v hodnotách $0,6-1,4$ hm. \%, což vylučuje zdrojovou lokalitu Paros.

\section{Vzorek 4027}

Ze srovnání hodnot stabilních izotopů $\delta^{13} \mathrm{C}$ a $\delta^{18} \mathrm{O}$ (viz obr. 3 a e-prŕloha 4) a hodnot MGS (obr. 5) přichází $\mathrm{v}$ úvahu zdrojové lokality Proconnesos, Paros-2 a Thasos-3, vyloučeny nejsou lokality Paros-1 a Thasos-1 (2). Identifikovaná asociace akcesorických minerálů zahrnuje: dolomit, křemen, muskovit, flogopit, apatit, titanit a pyrit. Z hlediska př́tomnosti flogopitu je možná provenience jak z Prokonnésu (Proconnesos-1) tak z Thasu (Thasos-3), nebot flogopit je typickou akcesorií nejen pro prokonnéský, ale i thaský mramor (Capedri, Venturelli 2004). Thaský a parský mramor však neobsahuje dolomit (Capedri et al. 2004), jenž je ve vzorku obsažen (0,6 hm. \%), čímž je provenience $z$ Thasu a Paru vyloučena (thaský mramor vykazuje kalcitické, nebo čiště dolomitické variety, (srov. Tůmová et al. 2016). Lze tedy konstatovat, že pravděpodobná provenience vzorku 4027 je Proconnesos (resp. Proconnesos 1).

\section{Vzorek 4168}

Ze srovnání hodnot stabilních izotopů $\delta^{13} \mathrm{C}$ a $\delta^{18} \mathrm{O}$ (viz obr. 3 a e-př́loha 4) a hodnot MGS (obr. 5) vychází jako možné provenience pouze lokality Proconnesos, nebo Paros-2, př́ípadně Paros-1. U vzorku 4168 byly jako akcesorické minerály identifikovány pouze dolomit, křemen, muskovit a apatit. Přestože ve vzorku nebyly identifikovány některé akcesorické minerály, které jsou typické pro lokalitu Proconnesos (flogopit, oxidy titanu apod.), kombinace výsledků hodnot stabilních izotopů $\delta^{13} \mathrm{C}$ a $\delta^{18} \mathrm{O}$ a MGS ukazují na možnou provenienci Proconnesos-1, Paros-1 a Paros-2. Vzhledem k př́tomnosti dolomitu ve vzorku $(0,7 \mathrm{hm}$. \%) lze vyloučit jako zdrojovou lokalitu Paros, nebot’ v parském mramoru prokázána nebyla (Capedri, Venturelli 2004). Provenienci mramoru je tedy s největší pravděpodobností možno určit jako Proconnesos, resp. Proconnesos 1 , jedná se tedy o rozšířenější varietu prokonnéského mramoru (viz Attanasio, Brilli, Bruno 2008).

\section{Vzorek 4317}

$\mathrm{Na}$ základě srovnání poměrů obsahů stabilních izotopů $\delta^{13} \mathrm{C}$ a $\delta^{18} \mathrm{O}$ (viz obr. 3 a př́loha 4 ) a hodnot MGS (obr. 5) připadají v úvahu lokality Proconnesos, Paros-2, nebo Afrodisias, nejsou vyloučeny ani lokality Paros-1 a Naxos. Přítomné akcesorické minerály jsou dolomit, křemen, muskovit, flogopit, pyrit, sfalerit a některý z polymorfů $\mathrm{TiO}_{2}$, fluorit.

Z hlediska přítomnosti dolomitu lze vyloučit jako zdrojovou lokalitu Paros a Naxos (Capedri, Venturelli 2004). V úvahu tedy připadají pouze lokality Proconnesos (1) a Afrodisias. U mramoru z Afrodisias je uváděn jako charakteristický akcesorický minerál plagioklas a muskovitická slída paragonit (Antonelli, Lazzarini 2015). Plagioklas ve vzorku 4317 identifikován nebyl, je zde 
však přítomen muskovit. Přítomnost flogopitu ukazuje na zdrojovou lokalitu Proconnesos, resp. Proconnesos-1. Vyhodnocení provedených analýz všech pěti studovaných vzorků ukazuje na podobnou provenienci u čtyř z nich $(238,4027,4168$ a 4317) z ostrova Proconnesos (varieta Proconnesos 1 nebo Proconnesos 2). Na základě srovnatelnosti obsahů stabilních izotopů $\delta^{13} \mathrm{C}$ a $\delta^{18} \mathrm{O}$ ve vzorcích 4027, 4168, 4317 a identických hodnot MGS lze zde usozovat na stejnou provenienci, a to Proconnesos 1. U vzorku 4164 není provenience zcela jednoznačná, jako nejpravděpodobnější se jeví lokality Göktepe (Muğla), nebo Docimium.

\section{Závěr}

Za účelem identifikace pravděpodobné provenience bylo na základě makroskopického vyhodnocení archeologického materiálu z klášterního komplexu San Severo v Classe pro studium vybráno pět vzorků bílo-šedého mramoru. Základními parametry, které byly srovnány s referenčními databázemi nejrozššřenějších bílých, resp. i bílo-šedých mramorů těžených v antice (Antonelli, Lazzarini 2015; Capedri, Venturelli 2004), byly obsahy stabilních izotopů $\delta^{13} \mathrm{C}$ a $\delta^{18} \mathrm{O}$, velikost zrn karbonátů a asociace akcesorických minerálů. Výsledky $s$ vysokou pravděpodobností potvrdily východní provenienci $\mathrm{z}$ antických lokalit, nacházejících se $\mathrm{v}$ dnešním pevninském a ostrovním Turecku. Vzorek 238 pochází pravděpodobně z Proconnesu (resp. jedná se o méně rozšířenou varietu Proconnesos 2), vzorky 4027, 4168 a 4317 z Proconnesu (resp. jedná se o rozšířenější varietu z lokality Proconnesos 1). Provenience vzorku 4164 není zcela jednoznačná, nicméně z uvažovaných maloasijských lokalit se jako nejpravděpodobnější jeví Göktepe (Muğla), př́padně Docimium. Prokonnéský mramor byl jedním $\mathrm{z}$ nejpoužívanějších mramorů $\mathrm{v}$ antice a jeho rozšíření je doloženo prakticky v celém Středomoří. Z lomů v Proconnesu se vyvážel hojně již od 2. pol. 2. stol. (Attanasio, Brilli, Bruno 2008).

Provenience z Prokonnésu, jež se pro oblast Ravenny obecně předpokládá, byla tedy stanovena u čtyř z pěti zkoumaných vzorků $(238,4027,4168,4317)$. Navržená provenience $\mathrm{v}$ souladu s historickými daty potvrzuje předpokládanou převažující východní orientaci pozdně antických obchodních kontaktů Ravenny s regiony východořímské říše, zejména se západními oblastmi dnešního Turecka.

Vzhledem k tomu, že v 8. stol. již byla činnost př́stavu v Classe zásadním způsobem omezená, a že se př́stav nacházel ve špatném technickém stavu, v neposlední řadě že docházelo k pozvolnému, leč nezvratnému procesu zanášení mořského dna, není pravděpodobné, že by Ravenna figurovala i v raném a vrcholném středověku v dálkovém (zámořském) obchodu. Přestože vybrané vzorky pocházejí z vrstev kláštera datovaných od 11 . do 15. stol., je nutné vycházet $\mathrm{z}$ předpokladu, že mramor ze vzdálených středomořských oblastí byl do přístavu $\mathrm{v}$ Classe dovezen dříve, než byl použit $\mathrm{v}$ rámci četných přestaveb klášterního komplexu. Je proto zřejmé, že byl v průběhu středověkých přestaveb využíván starší materiál z okolních nepoužívaných staveb, případně z dochovaných zásob mramoru $\mathrm{v}$ prrístavních depositech, které u prŕístavu v Classe s největší pravděpodobností existovaly.

\section{Poděkování}

Tato práce vznikla za podpory projektu „Kreativita a adaptabilita jako předpoklad úspěchu Evropy v propojeném svètě" reg. č.: CZ.02.1.01/0.0/0.0/16_019/0000734, financovaného z Evropského fondu pro regionální rozvoj; a za finanční podpory Ministerstva dopravy v rámci programu dlouhodobého koncepčního rozvoje výzkumných organizací. 


\section{Literatura}

Amadori, M. L., Lazzarini, L., Mariottini, M., Pecoraro, M., Pensabene, P. (1998). Determinazione della provenienza dei marmi usati per alcuni monumenti antichi di Roma. - In: Pensabene, P. (ed.): Marmi Antichi. II. Cave e tecnica di lavorazione, provenienze e distribuzione, Studi Miscellanei, 31, Rím, 45-55.

Antonelli, F., Santi, P., Renzulli, A., Santoro Bianchi, S. (2016). The architectural reuse of Roman marble and stone spolia in the Early Medieval Monte Sorbo church (Sarsina, central Italy), in Archaeometry 58, 3 (2016), 353-370. https://doi.org/10.1111/ arcm.12170

Attanasio, D., Brilli, M., Ogle. N. (2006). The Isotopic Signature of Classical Marbles, series: Studia Archaeologica (Book 145), Rome, $336 \mathrm{~s}$.

Attanasio, D., Brilli, M., Bruno, M. (2008). The Properties and Identification of Marble from Proconnesos (Marmara Island, Turkey): A New Data Including Isotopic, EPR and Petrographic Data. - Archaeometry 50(5), 747-774. https://doi.org/10.1111/j.1475-4754.2007.00364.x

Augenti, A., Cirelli, E. (2010). Classe: un osservatorio privilegiato per il commercio della tarda antichitá. - In: Menchelli, S., Santoro, S., Pasquinucci, M., Guiducci, G. (eds): BAR International Series 2185 (II) 2010: LRCW3. Late Roman Coarse Wares, Cooking Wares and Amphorae in the Mediterranean. Archaeology and archaeometry. Comparison between western and eastern Mediterranean., Oxford: Archaeopress, s. 605-615.

Augenti, A., Begnozzi, I., Bondi, M., Cirelli, E., Ferreri, D., Malaguti, C., Scozzari, P. (2012). Il monastero di San Severo a Classe: risultati delle campagne di scavo 2006-2011, VI Congresso nazionale di archeologia medievale, 238-245.

Augenti, A. (2017). Classe. La topografia, i monumenti. In: Augenti, A., Christie, N., Laszlovsky, J., Ripoll, G.(eds): La Basilica di San Severo a Classe. Scavi 2006. Bononia University Press. ISBN: 978-88-6923-174-2. 254 s., 2-3.

Cameron, A. (1993). The Later Roman Empire (AD 284-430), Cambridge, 238 s.

Capedri, S. Venturelli, G. (2004). Accesory minerals as tracers in the provenancing of archaeological marbles, used in combination with isotopic and petrographic data. - Archaeometry 46, 4 (2004), 517-536. https://doi.org/10.1111/j.1475-4754.2004.00171.x

Capedri, S., Venturelli, G., Photiades, A. (2004). Accessory minerals and $\delta^{18} \mathrm{O}$ and $\delta^{13} \mathrm{C}$ of marbles from the Mediterranean area. - Journal of Cultural Heritage, 5, 27-47.

Farioli, R. (1969). La scultura architettonica. Basi, capitelli, pietre d'imposta, pilastri e pilastrini, plutei, pulvini. - In: Bovini, G. (ed.): Corpus III, Corpus della scultura paleocristiana bizantina ed altomedievale di Ravenna. Rím, 1-91.

Farioli, R. (1983). Edifici paleocristiani di Classe: Stato attuale delle ricerche e problemi. - In: Montanari, G. B. (ed.): Ravenna e il porto di Classe: venti anni di ricerche archeologiche tra Ravenna e Classe, Bologna, 23-51.

Christie, N. (2017). The Basilica and the mausolea. - In: Augenti, A., Christie, N., Laszlovsky, J., Ripoll, G. (eds): La Basilica di San Severo a Classe. Scavi 2006. Bononia University Press, 254 s., 3-4.

Martinelli, P.A. (1968). Altari, amboni, cibori, cornici, plutei con figure di animali e con intrecci, transenne e frammenti vari. - In: Bovini, G. (ed.) Corpus I, Corpus della scultura paleocristiana bizantina ed altomedievale di Ravenna, Rím, 1-85.

Moropoulou, A., Delegou, E.T., Apostolopoulou, M., Kolaiti, A., Papatrechas, Ch., Economou, G., Mavrogonatos, C. (2019). The White Marbles of the Tomb of Christ in Jerusalem: Characterization and Provenance. - Sustainability, 11, 2495, open access: https://www.mdpi.com/2071-1050/11/9/2495/htm, 1-32.

Prochaska, W., Attanasio, B. (2012). Tracing the origin of marbles by inclusion fluid chemistry. - In: Gutiérrez Garcia-M. A., Lapuente Mercadal, P., Rodà de Llanza, I. (eds): Interdisciplinary Studies on Ancient Stone. Proceedings of the IX Association for the Study of Marbles and Other Stones in Antiquity (ASMOSIA) Conference (2009), Tarragona, 230-237.

Rizzardi, C. (2016). Ravenna, il suo porto e i suoi orizzonti mediterranei: 1'importazione di materiali marmorei fra dinamiche commerciali ed ideologiche (V - VI secolo), Hortus Artium Medievalium, Vol. 22, 190-199.

Sekavová, H. (2006). Ravennské figurální a symbolické sarkofágy 4.-6. st. po Kr. Ikonografie, typologie a chronologie ravennských sarkofágů. Diplomová práce. Filozofická fakulta Univerzity Karlovy, $183 \mathrm{~s}$.

Tischendorf, G., Gottesmann, B., Foerster, H. J., Trumbull, R. B. (1997). On Li-bearing micas: estimating Li from electron microprobe analyses and an improved diagram for graphical representation. Mineralogical Magazine, 61(409), 809-834.

Tůmová, H. 2013. Il commercio del marmo a Ravenna nella Tarda Antichità: i materiali del complesso di San Severo, Ph.D. Thesis, Filozofická fakulta Karlovy Univerzity v Praze, Università degli Studi di Bologna.

Tůmová, H., Augenti, A., Kuchařová, A., Cirelli, E., Přikryl, R. (2016). Late Antique marble trade: new insights obtained from stone artefacts from the San Severo complex (Ravenna, Italy). - In: Přikryl, R., Török, Á., Gomez-Heras, M., Miskovsky, K. \& Theodoridou, M. (eds): Sustainable Use of Traditional Geomaterials in Construction Practice. Geological Society, London, Special Publications, 416., 35-46.

Tůmová, H., Cirelli, E. (2019). Reimpiego e spolia nella tarda Antichità alla luce del materiale litico proveniente dal complesso archeologico di San Severo a Classe. - Studia Hercynia, XXIII/1, 55-78. http://hdl.handle.net/20.500.11956/117074.

Valenti Zucchini G., Bucci, M. (1968). I sarcofagi a figure e a carattere simbolico. - In: Bovini, G. (ed.): Corpus II, Corpus della scultura paleocristiana bizantina ed altomedievale di Ravenna. Rím, 1-66.

Zöldföldi, J., Satir, M. (2003). Provenance of the White Marble Building Stones in the Monuments of Ancient Troia. - In: Wagner, G.A., Pernicka E., Uerpmann HP. (eds): Troia and the Troad, Natural Science in Archaeology. Springer, Berlin, Heidelberg, 203-222.

\section{Použité zkratky}

LPR Andreas Agnellus Ravennatensis. Liber pontificalis ecclesiae Ravennatis [online], in Carducci, G. - Fiorini, V. 1917: Rerum Italicarum Scriptores. Raccolta degli storici italiani dal cinquecento al millecinquecento ordinata da L. A. Muratori Tomo II - Parte III, Bologna: Nicola Zanichelli. Dostupné na: http://www.documentacatholicaomnia.eu/04z/z_0805-0846__Agnellus_[Andreas]_Ravennatensis__Liber_Pontificalis_Ecclesiae_Ravennatis__LT.doc.html, 13. 11. 2020. 